\title{
"Corporate social responsibility disclosure and profitability: Evidence from Islamic banks working in Yemen"
}

\begin{tabular}{|c|c|}
\hline \multirow{5}{*}{ AUTHORS } & Nabil Ahmed Mareai Senan (iD) \\
\hline & Aida Abdulaziz Ali Noaman (iD) \\
\hline & Borhan Omar Ahmad Al-dalaien (i) \\
\hline & Eissa A. Al-Homaidi (D) \\
\hline & $\mathbf{R}$ \\
\hline ARTICLE INFO & $\begin{array}{l}\text { Nabil Ahmed Mareai Senan, Aida Abdulaziz Ali Noaman, Borhan Omar Ahmad } \\
\text { Al-dalaien and Eissa A. Al-Homaidi (2021). Corporate social responsibility } \\
\text { disclosure and profitability: Evidence from Islamic banks working in Yemen. } \\
\text { Banks and Bank Systems, 16(2), 91-102. doi:10.21511/bbs.16(2).2021.09 }\end{array}$ \\
\hline DOI & http://dx.doi.org/10.21511/bbs.16(2).2021.09 \\
\hline RELEASED ON & Tuesday, 01 June 2021 \\
\hline RECEIVED ON & Tuesday, 06 April 2021 \\
\hline \multirow[t]{2}{*}{ ACCEPTED ON } & Tuesday, 25 May 2021 \\
\hline & 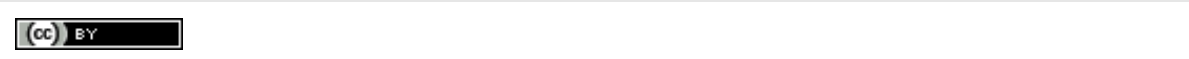 \\
\hline LICENSE & $\begin{array}{l}\text { This work is licensed under a Creative Commons Attribution } 4.0 \text { International } \\
\text { License }\end{array}$ \\
\hline JOURNAL & "Banks and Bank Systems" \\
\hline ISSN PRINT & $1816-7403$ \\
\hline ISSN ONLINE & $1991-7074$ \\
\hline PUBLISHER & LLC "Consulting Publishing Company "Business Perspectives" \\
\hline FOUNDER & LLC "Consulting Publishing Company "Business Perspectives" \\
\hline
\end{tabular}

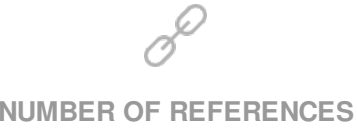

32

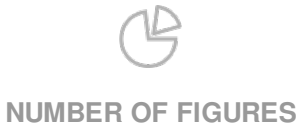

0

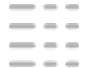

NUMBER OF TABLES

6

(C) The author(s) 2021. This publication is an open access article. 


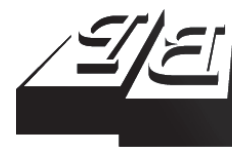

\section{BUSINESS PERSPECTIVES}

LLC "CPC "Business Perspectives" Hryhorii Skovoroda lane, 10, Sumy, 40022, Ukraine www.businessperspectives.org
Received on: $6^{\text {th }}$ of April, 2021 Accepted on: $25^{\text {th }}$ of May, 2021 Published on: $1^{\text {st }}$ of June, 2021

(C) Nabil Ahmed Mareai Senan, Aida Abdulaziz Ali Noaman, Borhan Omar Ahmad Al-dalaien, Eissa A. AlHomaidi, 2021

Nabil Ahmed Mareai Senan, Associate Professor, Department of Accounting College of Business Administration, Prince Sattam bin Abdul Aziz University and Administrative Science College, Al-Baydha University, Kingdom of Saudi Arabia.

Aida Abdulaziz Ali Noaman, Assistant Professor, Community College, Department of Business Administration, Najran University, Kingdom of Saudi Arabia.

Borhan Omar Ahmad Al-dalaien, Assistant Professor, Faculty of Business, Accounting Department, Amman Arab University (AAU), Amman, Jordan.

Eissa A. Al-Homaidi, Assistant Professor, Faculty of Business, Al-Rowad University, Taiz, Yemen. (Corresponding author)
Nabil Ahmed Mareai Senan (Kingdom of Saudi Arabia), Aida Abdulaziz Ali Noaman (Kingdom of Saudi Arabia), Borhan Omar Ahmad Al-dalaien (Jordan), Eissa A. Al-Homaidi (Yemen)

\section{CORPORATE SOCIAL} RESPONSIBILITY DISCLOSURE AND PROFITABILITY: EVIDENCE FROM ISLAMIC BANKS WORKING IN YEMEN

\begin{abstract}
This study aims to examine the influence of corporate social responsibility (CSR) disclosure determinants on profitability of Yemeni Islamic financial institutions. The empirical study was based on a balanced panel for twelve years from 2005 to 2016. Banks' profitability is measured by four indicators such as return on assets (ROA), return on equity (ROE), profit after tax (PAT), and earnings per share (EPS), while corporate social responsibility, financial leverage, inflation rate, asset size, and age of Islamic banks are considered as independent variables. The results of this study with regard to ROA indicated that corporate social responsibility, asset size, inflation rate, and age of Islamic banks have a significant influence on profitability (ROA). With respect to ROE, the result indicated that financial leverage, asset size, and inflation rate are the most important variables affecting bank profitability (ROE). Concerning PAT, the outcome revealed that financial leverage and age of Islamic banks have a significant effect on profitability (PAT). Finally, the result with respect to EPS indicated that financial leverage, asset size, inflation rate, and age of Islamic banks have a significant impact on bank profitability (EPS). The result will be beneficial to scholars, investors, stakeholders, managers, and policymakers in the Islamic financial sector.
\end{abstract}

\section{Keywords Islamic banking, information disclosure, profitability, corporate social responsibility, Yemen}

\section{JEL Classification $\quad$ M14, M41, G21, L25}

\section{INTRODUCTION}

According to the growing public concern about corporate impacts on society and the environment, "corporate social responsibility" (CSR) disclosure and social reporting have become a crucial issue for many companies. Corporate social responsibility has been around for decades and is now rising at an incredible rate with no signs (Quazi et al., 2015). Avoiding unethical behavior and obtaining 'social authorization' (Gunningham et al., 2004, p. 308) have led to an increased number of firms getting involved in preparing CSR sustainability reports published.

The main objective of corporate social responsibility disclosure is to achieve an "ethical and socially responsible approach to the stakeholders of the company" (Hopkins, 2004). The principles of "corporate social responsibility" are consistent with the services of Islamic institutions in different countries following Islamic law. Each person is responsible for promoting equality and prosperity in society, as well as seeking the blessings of God for the sake of prosperity in this life and the hereafter. Despite the importance of "corporate social responsibil- 
ity" disclosure in demonstrating disclosure, transparency and Islamic ethical decision-making among managers, auditors, and members of the Sharia Board (Ethical Law) (Sharia Supervisory Board, SSB), much is not known about the importance of corporate social responsibility disclosure practices in the annual reports of banks of Islamic finance and banking (Hassan \& Harahap, 2010).

According to the available literature, CSR reporting has been prioritized in the "majority of developed countries where social responsibility disclosure is more common". According to Belal (2008) and Momin (2006), CSR research in developing countries is still in its early stages. Furthermore, Visser et al. (2008) found out how the definition of CSR varies in emerging and industrialized countries due to variations in social and political contexts. As a result, this study examines social responsibility reporting of selected packed Islamic financial institutions in Yemen to fill a void in the literature and to examine Islamic banks' "social responsibility reporting" in developing countries. The explanation for choosing Yemen is that it is heavily supporting the Islamic financial system. Furthermore, this nation is situated in the region and is classified as a developing economy.

\section{LITERATURE REVIEW}

Many empirical studies examined the association between CSD in Islamic banks and banks' profitability in different countries such as Amran et al. (2017), Bolanle et al. (2012), Chen et al. (2018), Chiang et al. (2015), Farook et al. (2011), Lee and Yang (2021), Lin et al. (2019), Long et al. (2020), Maqbool and Bakr (2019), Maqbool and Zamir (2019), Mirfazli (2008), Ompusunggu (2016), Platonova et al. (2016), Rahman and Bukair (2013), Ridwan and Mayapada (2020), Rodrguez and Lemaster (2007), Szegedi et al. (2020), Tran et al. (2021), Wuttichindanon (2017).

Bolanle et al. (2012) indicated the correlation between "corporate social responsibility" and benefit. The regression results indicated that "corporate social responsibility" spending has an effect on profitability in the Nigerian banking industry (Beta $=0.945$, p.01). Rahman and Bukair (2013) studied empirically and reported the impact of the "Shariah supervisory board" (SSB) and its features on the level of CSR disclosure. The findings revealed that the volume of CSR data reported in Islamic banks' annual reports has risen. Ompusunggu (2016) investigated the effect of benefit on the disclosure of "corporate social responsibility" (CSR) transparency. The findings of this review show that CSR transparency has a major effect on profitability through "ROA, ROE, and NPM". ROA and NPM have a positive impact on CSR transparency, while ROE has a negative effect.
Chiang et al. (2015) investigated the connection between "corporate social responsibility and financial reporting quality." Companies can easily minimize their level of earnings control and offer quality financial reporting by practicing CSR, according to the analytical findings of the total samples. Platonova et al. (2016) demonstrated the link between "corporate social responsibility" (CSR) and financial success in Gulf Cooperation Council Islamic banks (GCC). The banks sampled were recorded in the analysis. According to the results of this report, there is an important positive link between CSR transparency and Islamic banks' financial success in the GCC region. Amran et al. (2017), exploring two developed nations, Indonesia and Malaysia, considered the social responsibility monitoring of full-fledged Islamic banks. The study's findings revealed that Islamic banks' CSR disclosure has risen in Malaysia and Indonesia. The workplace and group aspects were discovered to be the most widely revealed fields by Islamic banks in both countries. Wuttichindanon (2017) examined the determinants of "corporate social responsibility" (CSR) disclosure of companies listed on the Thai Stock Exchange, as well as report options used for CSR disclosure (SET). The findings revealed that big or government-owned businesses are more likely to favor the sustainability study.

Chen et al. (2018) examined the effect of mandatory "corporate social responsibility" (CSR) transparency on firm results and social external costs. Mandatory CSR reporting companies suffer a drop in productivity since the mandate, according to the study. Maqbool and Zamir (2019) in- 
vestigated Indian corporations' "corporate social responsibility" (CSR) transparency. The findings show that 'mining and mineral' companies are the most vocal about CSR disclosure, accompanied by 'power sector' firms. Maqbool and Bakr (2019) investigated the correlation between "corporate social responsibility (CSR) and financial performance" (FP), which has sparked a lot of discussion among academics. The results show that CSR and FP have a curvilinear relationship, implying that two long opposing views can be complementary. Lin et al. (2019) tested the influence of CSR factors on a company's financial performance. According to the report, allocating resources to diversity, human rights, workplace treatment, wages, insurance, recruitment, wellness, and workforce protection will help an organization to build value.

However, most empirical studies examined the association between CSR and financial performance such as Ridwan and Mayapada (2020); also, the influence of sharia governance on corporate social responsibility transparency in the Indonesian Islamic industry was examined. Szegedi et al. (2020) tested the influence of "sharia governance on corporate social responsibility disclosure in Indonesian Islamic banks". The results show that financial institutions are involved in CSR operations and that adequate transparency has helped to boost their accounting-based financial efficien$c y$, as measured by "return on equity (ROE) and return on assets (ROA)". The researchers looked at whether the effect of a company's CFP varies based on its degree of CSR output and annual operational expense. The results found that the correlation between a company's operating expenses and productivity is non-linear and that operating spending has a more substantial and detrimental effect on the financial performance at certain CSR score thresholds (Lee \& Yang, 2021). The partnership between benefit and "corporate social responsibility" transparency was investigated. Return on assets (ROA) and net interest margin (NIM) have opposite effects on the CSRD dependent factor, but return on equity (ROE) has a little impact on CSRD, whereas CSRD has a separate impact on the productivity dependent factor than ROA, ROE, and NIM (Tran et al. 2021). Table 1 shows the summary of empirical studies that examined the link between CSD and financial performance in different countries.
Accordingly, this paper aims to study the link between corporate social responsibility disclosure factors with Islamic banks' profitability in Yemen during the period of examination from 2006 to 2016. Bank profitability is considered as a dependent variable, whereas corporate social responsibility factors are considered as independent variables. This review bridges the existing gap in the corporate social responsibility disclosure and bank profitability literature in the Republic of Yemen.

\section{METHODS}

This study applies a quantitative method. The Bank Scope Database and the websites of the sample Islamic banks are used to compile annual financial reports. The sample of the study consists of three Islamic financial institutions during the period from 2005 to 2016 . The study is based on secondary data collected from the annual reports. The dependent variable of this study is bank profitability measured by four indicators such as return on assets (ROA), return on equity (ROE), profit after tax (PAT), and earnings per share (EPS). The independent variable of this study is measured by five factors such as corporate social responsibility, financial leverage, inflation rate, asset size, and age of Islamic banks.

The un-weighted content analysis approach is used to analyze the CSR disclosures through annual reports, ensuring the quality and reliability of the analysis. As a result, ' 1 ' is assigned to each CSR disclosed in the financial statement, and ' 0 ' is assigned to the annual report if no CSR disclosure items are disclosed otherwise (see Cooke, 1989) as follows:

$$
T V D S=\sum_{j=1} \frac{d j}{n},
$$

where TVDS is the cumulative score for corporate social responsibility disclosure), $d j$ is 1 if shown by Islamic firms, or 0 otherwise, and $n$ is the maximum score for each Islamic institution.

A total of 10 disclosure index items of CSR are developed based on previous studies such as Hossain (2008), Hossain and Hammami (2009), Barros et al. (2013), Hawashe (2014), which are related to financial institutions' CSR reporting requirements. 


\begin{tabular}{|c|c|c|c|c|c|}
\hline Author & Country & Sample & Data & Period & Results \\
\hline $\begin{array}{l}\text { Rodrguez and } \\
\text { Lemaster (2007) }\end{array}$ & Gulf region & $\begin{array}{l}21 \text { conventional } \\
\text { banks and } 21 \\
\text { Islamic banks }\end{array}$ & \multirow{9}{*}{ 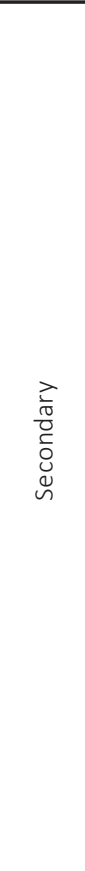 } & 2004 & $\begin{array}{l}\text { The results showed significant differences in the level and the extent of the disclosure between IFIs and CFIs, } \\
\text { largely due to the disclosure made by IFIs of religions-related themes and information, including Shari'a supervisory } \\
\text { board reports, the Zakah and charity donation, and free interest loan. }\end{array}$ \\
\hline Mirfazli (2008) & Indonesia & 42 companies & & 2004 & $\begin{array}{l}\text { The results indicated that the main foci of social disclosure from companies registered at the Indonesia Stock } \\
\text { Exchange are labor theme ( } 51.60 \text { percent), followed by customer theme (19.40 percent), society theme (14.70 } \\
\text { percent) and environmental theme ( } 14.30 \text { percent), respectively. }\end{array}$ \\
\hline Farook et al. (2011) & in 14 countries & 47 Islamic banks & & 2000 & $\begin{array}{l}\text { Corporate social responsibility (CSR) disclosure by Islamic banks varies significantly across the sample. According } \\
\text { to the regression results, variation is best explained by the influence of the relevant publics and the Shari'ah (SSB } \\
\text { supervisory boards) corporate governance mechanism variables. }\end{array}$ \\
\hline Bolanle et al. (2012) & Nigerian & 1 bank & & 2001-2010 & $\begin{array}{l}\text { The results of the review suggested that corporate social responsibility expenditure affects profitability of Nigeria's } \\
\text { banks }(\text { Beta }=0.945, p<.01) \text {. }\end{array}$ \\
\hline $\begin{array}{l}\text { Rahman and Bukair } \\
\text { (2013) }\end{array}$ & GCC) & 53 banks in & & 2008 & The study showed that there is an increase in CSR information disclosed in the annual reports of Islamic banks. \\
\hline Ompusunggu (2016) & Indonesian & $\begin{array}{l}63 \text { mining } \\
\text { companies }\end{array}$ & & $2010-2012$ & $\begin{array}{l}\text { The results of this study showed that there are significant effects on profitability through ROA, ROE, and NPM on } \\
\text { the disclosure of CSR. ROA and NPM have positive effects on the disclosure of CSR, while ROE negatively affects } \\
\text { CSR disclosure. }\end{array}$ \\
\hline Chiang et al. (2015) & U.S. & 442 companies & & $\begin{array}{c}2009-2011 \\
\text { editions }\end{array}$ & $\begin{array}{l}\text { The empirical results of the overall samples indicated that by practicing CSR, companies can effectively reduce } \\
\text { their level of earnings management, providing quality financial reports. }\end{array}$ \\
\hline Platonova et al. (2016) & $\begin{array}{l}\text { Five GCC } \\
\text { countries }\end{array}$ & 24 Islamic banks & & $2000-2014$ & $\begin{array}{l}\text { The outcomes report the sampled banks. The findings of this study indicate that there is a significant positive } \\
\text { relationship between CSR disclosure and the financial performance of Islamic banks in the GCC countries. }\end{array}$ \\
\hline Amran et al. (2017) & $\begin{array}{l}\text { Indonesia and } \\
\text { Malaysia }\end{array}$ & 6 Islamic banks & & $2007-2011$ & $\begin{array}{l}\text { The results revealed that CSR disclosure of Islamic banks has generally grown both in Malaysia and Indonesia. More } \\
\text { specifically, it was found that workplace and community dimensions were the most highly disclosed areas by the } \\
\text { Islamic banks in both countries. }\end{array}$ \\
\hline
\end{tabular}


Table 1 (cont.). Some empirical articles that examined the link between CSD and financial performance.

\begin{tabular}{|c|c|c|c|c|c|}
\hline Author & Country & Sample & Data & Period & Results \\
\hline $\begin{array}{l}\text { Wuttichindanon } \\
\text { (2017) }\end{array}$ & Thailand & 451 firm & \multirow{12}{*}{$\begin{array}{l}\vec{z} \\
\frac{\pi}{0} \\
\overline{0} \\
0 \\
\stackrel{u}{n}\end{array}$} & 2014 & The results revealed that government-owned firms or large firms are more likely to prefer the sustainability report. \\
\hline Chen et al. (2018) & China & $\begin{array}{l}1674 \text { treatment } \\
\text { firm- and } 5278 \\
\text { benchmark firm- }\end{array}$ & & $\begin{array}{l}2006 \text { to } \\
2011\end{array}$ & $\begin{array}{l}\text { The study found that mandatory CSR reporting firms experience a decrease in profitability after the mandate. In } \\
\text { addition, the cities most impacted by the disclosure mandate experience a decrease in their industrial wastewater } \\
\text { and SO2 emission levels. }\end{array}$ \\
\hline $\begin{array}{l}\text { Maqbool and Zamir } \\
\text { (2019) }\end{array}$ & Indian & $\begin{array}{l}30 \text { listed } \\
\text { companies }\end{array}$ & & $2016-2017$ & $\begin{array}{l}\text { The results showed that the CSR disclosure is pronouncedly communicated by 'mining and mineral' companies, } \\
\text { followed by 'power sector companies. }\end{array}$ \\
\hline $\begin{array}{l}\text { Maqbool and Bakr } \\
\text { (2019) }\end{array}$ & Indian & $\begin{array}{l}43 \text { listed } \\
\text { companies }\end{array}$ & & $\begin{array}{l}2008 \text { to } \\
2017\end{array}$ & $\begin{array}{l}\text { The findings demonstrated that a curvilinear relationship exists between CSR and FP, suggesting that two long } \\
\text { competing viewpoints may be complementary. }\end{array}$ \\
\hline Lin et al. (2019) & Taiwan & 83 firm & & $\begin{array}{l}01 / 2009 \text { to } \\
07 / 2014\end{array}$ & $\begin{array}{l}\text { The study indicated that allocating resources to diversity, labor rights, treatment of unions, compensation, } \\
\text { benefits, training, health, and worker safety can be beneficial to a firm's value creation. }\end{array}$ \\
\hline $\begin{array}{l}\text { Ridwan and Mayapada } \\
\text { (2020) }\end{array}$ & Indonesia & 10 Islamic banks & & $\begin{array}{l}2011 \text { to } \\
2018\end{array}$ & $\begin{array}{l}\text { This study found that the effectiveness of the board of directors plays a vital role in enforcing corporate social } \\
\text { responsibility disclosure. Whereas, the audit committee and sharia supervisory board are found to have no } \\
\text { significant effect on corporate social responsibility disclosure in Islamic banks. }\end{array}$ \\
\hline Szegedi et al. (2020) & Pakistan's & 20 banks & & $\begin{array}{l}2008 \text { to } \\
2018\end{array}$ & $\begin{array}{l}\text { The results suggested an increase in overall CSR disclosure by all banks in the sample, and the involvement of } \\
\text { commercial banks in CSR activities, and its proper disclosure has helped to improve their accounting-based } \\
\text { financial performance proxied by the return on equity (ROE) and return on assets (ROA). }\end{array}$ \\
\hline $\begin{array}{l}\text { Al-Homaidi et al. } \\
\text { (2020) }\end{array}$ & Yemen & 3 banks & & $\begin{array}{l}2005 \text { to } \\
2014\end{array}$ & $\begin{array}{l}\text { The findings indicate that the Islamic bank's background information, corporate governance information, corporate } \\
\text { social disclosure, bank size, and bank age all have a negative and substantial effect on return on assets. }\end{array}$ \\
\hline $\begin{array}{l}\text { Al-Homaidi et al. } \\
\text { (2021) }\end{array}$ & India & 33 firms & & $\begin{array}{l}2011 \text { to } \\
2014\end{array}$ & $\begin{array}{l}\text { The findings reveal that board diligence, the size of the audit committee, audit committee composition, and board } \\
\text { diligence are linked to return on assets. }\end{array}$ \\
\hline Long et al. (2020) & China & all listed firms & & $\begin{array}{l}2009 \text { to } \\
2013\end{array}$ & $\begin{array}{l}\text { The outcomes revealed that (a) CSR positively affects financial performance, (b) state ownership weakens the } \\
\text { relationship between CSR and financial performance, and (c) industry competition strengthens the relationship } \\
\text { between CSR and financial performance for both state-owned and non-state-owned firms. }\end{array}$ \\
\hline Lee and Yang (2021) & Taiwan & TOP 50 & & $\begin{array}{l}2013 \text { to } \\
2017\end{array}$ & $\begin{array}{l}\text { The findings revealed that the relationship between a firm's operating expenditures and its profitability is non- } \\
\text { linear, and with certain threshold values of CSR scores, operating spend has a more significant and negative effect } \\
\text { on profitability. }\end{array}$ \\
\hline Tran et al. (2021) & Vietnamese & 18 banks & & $\begin{array}{l}2015 \text { to } \\
2019\end{array}$ & $\begin{array}{l}\text { The study results showed that, with the CSRD as a dependent variable, return on assets (ROA) and net interest } \\
\text { margin (NIM) have an opposite influence, but return on equity (ROE) has no effect on CSRD, while CSRD has a } \\
\text { different influence through ROA, ROE, and NIM on the profitability dependent variable. }\end{array}$ \\
\hline
\end{tabular}




\subsection{Multiple regression and measurement of variables}

Multiple regression was applied to examine the association between Islamic banks' profitability and corporate social responsibility disclosure in Yemen.

$$
\begin{aligned}
& \text { PROF }_{i t}=a_{0}+ \\
& +a_{1} \text { Corporate social responsibility }_{i t}+ \\
& +a_{2} \text { Financial leverage }_{i t}+ \\
& +a_{3} \text { Inflation rate }_{i t}+a_{4} \text { Asset size }_{i t}+ \\
& +a_{5} \text { Age of Islamic bank }_{i t}+\varepsilon_{i t},
\end{aligned}
$$

where $P R O F=$ profitability ratio defined by 4 factors (ROA, PAT, ROE, and EPS), $t$ - number of

\begin{tabular}{|c|c|c|c|}
\hline Variables & Notation & Proxy/Measurement & $\begin{array}{l}\text { Ex. } \\
\text { sign }\end{array}$ \\
\hline \multicolumn{4}{|c|}{ Dependent factor } \\
\hline \multirow{4}{*}{$\begin{array}{l}\text { Bank } \\
\text { profitability }\end{array}$} & ROA & $\begin{array}{c}\text { Net profit after tax to total } \\
\text { assets }\end{array}$ & NA \\
\hline & ROE & $\begin{array}{l}\text { Net profit after tax to total } \\
\text { equity }\end{array}$ & NA \\
\hline & PAT & $\begin{array}{c}\text { Net income - dividends on } \\
\text { preferred stock)/average } \\
\text { outstanding shares }\end{array}$ & NA \\
\hline & EPS & $\begin{array}{l}\text { Net profit after tax } \\
\text { to numbers of equity } \\
\text { shareholders" }\end{array}$ & NA \\
\hline \multicolumn{4}{|c|}{ Independent variables } \\
\hline $\begin{array}{l}\text { Corporate } \\
\text { social } \\
\text { responsibility }\end{array}$ & CSRD & $\begin{array}{c}\text { Disclosure index, } 1 \text { if } \\
\text { the bank disclosed or } 0 \\
\text { otherwise }\end{array}$ & \pm \\
\hline $\begin{array}{l}\text { Financial } \\
\text { leverage }\end{array}$ & LEV & Debt to total assets & + \\
\hline Asset size & BSIZE & $\begin{array}{l}\text { The logarithm of total } \\
\text { assets }\end{array}$ & + \\
\hline Inflation rate & INF & Consumer price index (CPI) & - \\
\hline $\begin{array}{l}\text { Age of Islamic } \\
\text { bank }\end{array}$ & BAGE & Age of the banks in years & + \\
\hline
\end{tabular}
banks $(1, \ldots, 3), a_{1}-a_{5}$ is the coefficient of determinant indicators, and $\varepsilon$ is the term of error, and all other variables are as set out in Table 2 .

Table 2. Measurement of variables

\section{RESULTS}

\subsection{Descriptive analysis}

Table 3 shows the descriptive analysis result of this study that explores the factors of "corporate social responsibility" disclosure in Islamic financial firms' over the period from 2006 to 2016 . It was found that the mean value of return on as- sets (ROA), return on equity (ROE), profit after tax (PAT), earnings per share (EPS), corporate social responsibility, financial leverage, inflation rate, asset size, and age of Islamic bank is -4.04 , $3.41,13.18,7.59,-1.59,0.00,5.32,18.85,14.76$, respectively, median value is $-4.40,-1.62,14.83,9.69$, $-1.61,0.00,0.11,19.01,15.00$, respectively, maximum value is $-1.75,15.08,15.56,9.76,-0.92,0.02$, $22.00,20.08,21.00$, respectively, minimum value is $-12.55,-2.26,9.69,2.85,-2.30,-0.04,0.04$, $17.28,8.00$, and Std. Dev value is $1.97,7.87,2.45$, $3.20,0.40,0.01,9.40,0.96,3.69$, respectively. Table 3 indicates that the skewness and kurtosis values show normal distributions of this study.

\subsection{Correlation analysis}

Table 4 presents the results of the link between dependent (bank profitability) and independent (corporate social responsibility disclosure) variables in the Islamic industry in Yemen during the period of the study. The results of the study indicated that there is a positive link between profit after tax, earnings per share, and financial leverage with bank profitability (ROA, ROE, and PAT), while corporate social responsibility, inflation rate, and age of Islamic bank have a negative correlation with profitability defined by ROA, ROE, and PAT. However, financial leverage, inflation rate, asset size, and age of Islamic banks have a positive relationship with earnings per share (EPS), except it has a negative link with corporate social responsibility transparency in Islamic firms in Yemen. The results indicated no multicollinearity diagnosis as the p-value of variables is less than 80 .

\subsection{Determinants of ROA and ROE}

Table 5 shows the outcomes of model 1 and model 2. The result shows "pooled and fixed" effect models for two estimates. The findings revealed that the adjusted $\mathrm{R}$ square for the ROA model is 0.37 for a pooled model and 0.46 for a fixed model, while the outcomes offered that the adjusted $\mathrm{R}$ square for ROE is 0.47 for pooled and 0.45 for fixed-effect models. The results for both models 1 and 2 are fit because the p-value is less than 0.05 .

With regard to an ROA pooled model 1, the results show that asset size and age of Islamic banks have a highly significant effect on profitability at the 
Table 3. Descriptive analysis

\begin{tabular}{|c|c|c|c|c|c|c|c|c|c|}
\hline Variable & $\begin{array}{c}\text { Return } \\
\text { on } \\
\text { assets }\end{array}$ & $\begin{array}{l}\text { Return } \\
\text { on } \\
\text { equity }\end{array}$ & $\begin{array}{l}\text { Profit } \\
\text { after tax }\end{array}$ & $\begin{array}{l}\text { Earnings } \\
\text { per share }\end{array}$ & $\begin{array}{l}\text { Corporate social } \\
\text { responsibility }\end{array}$ & $\begin{array}{l}\text { Financial } \\
\text { leverage }\end{array}$ & $\begin{array}{c}\text { Inflation } \\
\text { Asset size } \\
\text { rate }\end{array}$ & $\begin{array}{l}\text { Asset } \\
\text { size }\end{array}$ & $\begin{array}{c}\text { Age of } \\
\text { Islamic } \\
\text { banks }\end{array}$ \\
\hline Mean & -4.04 & 3.41 & 13.18 & 7.59 & -1.59 & 0.00 & 5.32 & 18.85 & 14.76 \\
\hline Median & -4.40 & -1.62 & 14.83 & 9.69 & -1.61 & 0.00 & 0.11 & 19.01 & 15.00 \\
\hline Maximum & -1.75 & 15.08 & 15.56 & 9.76 & -0.92 & 0.02 & 22.00 & 20.08 & 21.00 \\
\hline Minimum & -12.55 & -2.26 & 9.69 & 2.85 & -2.30 & -0.04 & 0.04 & 17.28 & 8.00 \\
\hline Std. Dev. & 1.97 & 7.87 & 2.45 & 3.20 & 0.40 & 0.01 & 9.40 & 0.96 & 3.69 \\
\hline Skewness & -1.64 & 0.82 & -0.65 & -0.82 & -0.35 & -1.57 & 1.21 & -0.21 & -0.16 \\
\hline Kurtosis & 9.33 & 1.68 & 1.57 & 1.68 & 2.81 & 6.60 & 2.47 & 1.65 & 1.96 \\
\hline Obs. & 42 & 42 & 42 & 42 & 42 & 42 & 42 & 42 & 42 \\
\hline
\end{tabular}

level of $1 \%$ (p-value < 0.01$)$. The results also indicated that corporate social responsibility and age of Islamic banks have a negative correlation with firms' financial performance, whereas financial leverage, asset size, and inflation rate have a positive association with firms' financial profitability (ROA). With regard to (ROA) a fixed model 1, the outcome revealed that asset size and age of Islamic banks have a highly significant influence on firm profitability at the level of $1 \%$ (p-value $<0.01$ ), corporate social responsibility has a significant effect on $\mathrm{ROA}$ at the $10 \%$ (p-value $<0.1$ ), inflation rate has a significant effect on ROA at $5 \%$ (p-value < 0.05). The results also indicated that corporate social responsibility and age of Islamic banks have a negative link with ROA, whereas financial leverage, asset size, and inflation rate have a positive link with bank profitability (ROA).

With regard to ROE, the results of the study found that financial leverage and age of Islamic bank have a negative and significant effect on banks profitability (ROE) in pooled and fixed models, except the age of bank has a significant impact on ROE in a pooled model and insignificant effect in a fixed model. Asset size and inflation rate indicators have a significant impact on banks' financial profitability (ROE) in pooled and fixed models.

\subsection{PAT and EPS determinants}

Table 6 presents the results of model 3 and model 4. The results show pooled and fixed-effect models for two estimates. The findings revealed that the adjusted $\mathrm{R}$ square for a PAT model is 0.30 for pooled model effect and 0.25 for fixed model, whereas the adjusted R square for EPS is 0.94 for a pooled model and 0.57 for a fixed model. The results for both models, 3 and 4, are fit because the $\mathrm{p}$-value is less than 0.05 .

With regard to (PAT) pooled model 3, the result suggested that financial leverage, asset size, and age of Islamic industry have a significant influence on financial institutional banks' profitability (PAT), while corporate social responsibility and inflation rate have an insignificant influence on profitability (PAT). The results also indicated that corporate social responsibility and asset size have a negative association with profitability (PAT),

Table 4. Correlation analysis

\begin{tabular}{|c|c|c|c|c|c|c|c|c|c|}
\hline Variable & $\begin{array}{l}\text { Return on } \\
\text { assets }\end{array}$ & $\begin{array}{c}\text { Return on } \\
\text { equity }\end{array}$ & $\begin{array}{c}\text { Profit } \\
\text { after tax }\end{array}$ & $\begin{array}{l}\text { Earnings } \\
\text { per share }\end{array}$ & $\begin{array}{l}\text { Corporate social } \\
\text { responsibility }\end{array}$ & $\begin{array}{l}\text { Financial } \\
\text { leverage }\end{array}$ & $\begin{array}{c}\text { Inflation } \\
\text { rate }\end{array}$ & $\begin{array}{l}\text { Asset } \\
\text { size }\end{array}$ & $\begin{array}{c}\text { Age of } \\
\text { Islamic } \\
\text { bank }\end{array}$ \\
\hline Return on assets & 1.00 & - & - & - & - & - & - & - & - \\
\hline Return on equity & -0.23 & 1.00 & - & - & - & - & - & - & - \\
\hline Profit after tax & 0.12 & 0.25 & 1.00 & - & - & - & - & - & - \\
\hline Earnings per share & 0.13 & 0.10 & 0.20 & 1.00 & - & - & - & - & - \\
\hline $\begin{array}{l}\text { Corporate social } \\
\text { responsibility }\end{array}$ & -0.36 & -0.02 & -0.18 & -0.19 & 1.00 & - & - & - & - \\
\hline Financial leverage & 0.08 & 0.23 & 0.35 & 0.17 & 0.18 & 1.00 & - & - & - \\
\hline Inflation rate & -0.50 & -0.26 & -0.21 & 0.08 & 0.07 & -0.19 & 1.00 & - & - \\
\hline Asset size & 0.17 & -0.38 & -0.52 & 0.03 & 0.10 & -0.39 & 0.09 & 1.00 & - \\
\hline Age of Islamic bank & -0.31 & -0.23 & -0.59 & 0.06 & 0.22 & -0.46 & 0.61 & 0.71 & 1.00 \\
\hline
\end{tabular}


Table 5. ROA and ROE determinants

\begin{tabular}{|c|c|c|c|c|c|c|c|c|}
\hline \multirow[b]{2}{*}{ Variable } & \multicolumn{4}{|c|}{ Pooled } & \multicolumn{4}{|c|}{ Fixed } \\
\hline & Coeff. & Std. error & t-statistic & Prob. & Coeff. & $\begin{array}{l}\text { Std. } \\
\text { error }\end{array}$ & t-statistic & Prob. \\
\hline \multicolumn{9}{|c|}{ Model 1. Return on assets (ROA) } \\
\hline Constant & -32.72 & 10.25 & -3.19 & $0.00 * * *$ & -93.9 & 30.66 & -3.06 & $0.01^{* * *}$ \\
\hline Corporate social responsibility & -1.14 & 0.75 & -1.52 & 0.14 & -1.23 & 0.7 & -1.77 & $0.09^{*}$ \\
\hline Financial leverage & 21.55 & 24.19 & 0.89 & 0.38 & 22.69 & 22.37 & 1.01 & 0.32 \\
\hline Asset size & 1.93 & 0.59 & 3.28 & $0.00 * * *$ & 5.1 & 1.61 & 3.18 & $0.01 * * *$ \\
\hline Inflation rate & 0.05 & 0.03 & 1.58 & 0.13 & 0.06 & 0.03 & 2.06 & $0.05^{* *}$ \\
\hline Age of Islamic bank & -0.59 & 0.15 & -3.87 & $0.00 * * *$ & -0.62 & 0.14 & -4.38 & $0.00^{* * *}$ \\
\hline R-squared & \multicolumn{4}{|c|}{0.50} & \multicolumn{4}{|c|}{0.59} \\
\hline Adjusted R-squared & \multicolumn{4}{|c|}{0.37} & \multicolumn{4}{|c|}{0.46} \\
\hline Durbin-Watson stat & \multicolumn{4}{|c|}{1.43} & \multicolumn{4}{|c|}{1.72} \\
\hline F-statistic & \multicolumn{4}{|c|}{3.97} & \multicolumn{4}{|c|}{4.61} \\
\hline Prob. (F-statistic) & \multicolumn{4}{|c|}{0.01} & \multicolumn{4}{|c|}{0.00} \\
\hline \multicolumn{9}{|c|}{ Model 2. Return on equity (ROE) } \\
\hline Constant & 0.07 & 0.06 & 1.07 & 0.3 & 0.07 & 0.06 & 1.06 & 0.3 \\
\hline Corporate social responsibility & 0.35 & 0.20 & 1.75 & 0.1 & 0.72 & 0.69 & 1.04 & 0.31 \\
\hline Financial leverage & -0.05 & 0.02 & -3.33 & $0.00 * * *$ & -0.05 & 0.02 & -3.23 & $0.00^{* * *}$ \\
\hline Asset size & 0.00 & 0.00 & 2.76 & $0.01^{* * *}$ & 0.00 & 0.00 & 2.59 & $0.02 * *$ \\
\hline Inflation rate & 2.11 & 0.51 & 4.17 & $0.00 * * *$ & 2.1 & 0.52 & 4.07 & $0.00 * * *$ \\
\hline Age of Islamic bank & -0.02 & 0.01 & -2 & $0.06^{*}$ & -0.04 & 0.04 & -1.14 & 0.27 \\
\hline R-squared & \multicolumn{4}{|c|}{0.58} & \multicolumn{4}{|c|}{0.59} \\
\hline Adjusted R-squared & \multicolumn{4}{|c|}{0.47} & \multicolumn{4}{|c|}{0.45} \\
\hline Durbin-Watson stat & \multicolumn{4}{|c|}{2.31} & \multicolumn{4}{|c|}{2.32} \\
\hline F-statistic & \multicolumn{4}{|c|}{5.49} & \multicolumn{4}{|c|}{4.47} \\
\hline Prob. (F-statistic) & \multicolumn{4}{|c|}{0.00} & \multicolumn{4}{|c|}{0.01} \\
\hline
\end{tabular}

Note: $*, * *$, and ${ }^{* * *}$ denote significance levels of $10 \%, 5 \%$, and $1 \%$, respectively.

whereas financial leverage, inflation rate, and age of Islamic banks have a positive effect on bank profitability (PAT). With respect to (PAT) fixed model 3, the outcomes of the study showed that financial leverage and age of Islamic banks have a significant impact on PAT, while corporate social responsibility, asset size, and inflation rate have an insignificant influence on PAT. The findings also indicated that corporate social responsibility has a negative effect on PAT, whereas financial leverage, asset size, inflation rate, and age of Islamic banks have a positive link with banks profitability (PAT).

With regard to (EPS) pooled model 4, the outcome indicated that corporate social responsibility, financial leverage, and asset size have a strongly significant effect on firms' financial profitability (EPS), except the inflation rate has an insignificant correlation with EPS. Corporate social responsibility and asset size have a negative association with EPS, whereas financial leverage, inflation rate, and age of Islamic banks have a positive relationship with EPS. The results of a fixed model 4 suggest- ed that financial leverage, asset size, inflation rate, and age of Islamic banks have a significant impact on profitability (EPS), except corporate social responsibility has a negative and insignificant effect on EPS. The results also found that financial leverage, asset size, and inflation rate have a positive effect on financial profitability ratio (EPS), except age of Islamic banks has a negative effect on EPS.

\section{DISCUSSION}

This section discusses the current review for the period of this study. During the research, a highly important association was found between Islamic institutions' profitability and corporate social responsibility transparency. The outcomes of this study are similar to those of Bolanle et al. (2012) and Ompusunggu (2016) who revealed that corporate social responsibility transparency has an influence on Nigerian banks' profitability. The results are not similar to Platonova et al. (2016) who indicated that corporate social responsibility has an important positive 
Table 6. PAT and EPS determinants

\begin{tabular}{|c|c|c|c|c|c|c|c|c|}
\hline \multirow{2}{*}{ Variable } & \multicolumn{4}{|c|}{ Pooled } & \multicolumn{4}{|c|}{ Fixed } \\
\hline & Coeff. & Std. Error & t-Statistic & Prob. & Coeff. & Std. Error & t-Statistic & Prob. \\
\hline \multicolumn{9}{|c|}{ Model 3. Profit after tax (PAT) } \\
\hline Constant & 23.51 & 5.26 & 4.47 & $0.00 * * *$ & 14.16 & 0.21 & 68.21 & $0.00 * * *$ \\
\hline $\begin{array}{l}\text { Corporate social } \\
\text { responsibility }\end{array}$ & -0.49 & 0.36 & -1.36 & 0.19 & -0.46 & 0.37 & -1.25 & 0.23 \\
\hline $\begin{array}{l}\text { Financial } \\
\text { leverage }\end{array}$ & 24.56 & 11.52 & 2.13 & $0.05^{* *}$ & 24.18 & 12.86 & 1.88 & $0.08^{*}$ \\
\hline Asset size & -0.48 & 0.27 & -1.8 & $0.09 *$ & 0.39 & 0.69 & 0.57 & 0.57 \\
\hline Inflation rate & 0.03 & 0.03 & 1.09 & 0.29 & 0.04 & 0.02 & 1.75 & 0.1 \\
\hline $\begin{array}{l}\text { Age of Islamic } \\
\text { bank }\end{array}$ & 21.92 & 9.93 & 2.21 & $0.04^{* *}$ & 22.52 & 6.83 & 3.29 & $0.00 * * *$ \\
\hline R-squared & 0.44 & - & - & - & 0.43 & - & - & - \\
\hline $\begin{array}{l}\text { Adjusted } \\
\text { R-squared }\end{array}$ & 0.30 & - & - & - & 0.25 & - & - & - \\
\hline $\begin{array}{l}\text { Durbin-Watson } \\
\text { stat }\end{array}$ & 1.08 & - & - & - & 0.98 & - & - & - \\
\hline F-statistic & 3.12 & - & - & - & 2.4 & - & - & - \\
\hline Prob(F-statistic) & 0.03 & - & - & - & 0.07 & - & - & \\
\hline \multicolumn{9}{|c|}{ Model 4. Earnings per shares (EPS) } \\
\hline Constant & $24,815.11$ & $1,374.61$ & 18.05 & $0.00^{* * *}$ & $-11,335.2$ & $9,421.24$ & -1.2 & 0.24 \\
\hline $\begin{array}{l}\text { Corporate social } \\
\text { responsibility }\end{array}$ & -407 & 118.17 & -3.44 & $0.00 * * *$ & -240.32 & 285.83 & -0.84 & 0.41 \\
\hline $\begin{array}{l}\text { Financial } \\
\text { leverage }\end{array}$ & $13,159.89$ & $2,987.79$ & 4.4 & $0.00 * * *$ & $25,684.3$ & $7,596.58$ & 3.38 & $0.00 * * *$ \\
\hline Asset size & -494.18 & 75.54 & -6.54 & $0.00 * * *$ & $1,409.43$ & 484.18 & 2.91 & $0.01 * * *$ \\
\hline Inflation rate & 0.74 & 4.22 & 0.17 & 0.86 & 27.04 & 9.71 & 2.78 & $0.01 * * *$ \\
\hline $\begin{array}{l}\text { Age of Islamic } \\
\text { bank }\end{array}$ & 868.07 & 421.77 & 2.06 & $0.05^{* *}$ & -127.08 & 49.38 & -2.57 & $0.02 * *$ \\
\hline R-squared & 0.95 & - & - & - & 0.67 & - & - & - \\
\hline $\begin{array}{l}\text { Adjusted } \\
\text { R-squared }\end{array}$ & 0.94 & - & - & - & 0.57 & - & - & - \\
\hline $\begin{array}{l}\text { Durbin-Watson } \\
\text { stat }\end{array}$ & 2.07 & - & - & - & 2.33 & - & - & - \\
\hline F-statistic & 81.96 & - & - & - & 6.53 & - & - & - \\
\hline Prob(F-statistic) & 0.00 & - & - & - & 0.00 & - & - & - \\
\hline
\end{tabular}

Note: $*, * *$, and $* * *$ denote significance levels of $10 \%, 5 \%$, and $1 \%$, respectively.

relationship with financial performance. Tran et al. (2021) showed that profitability (ROA and NIM) has an opposite influence on CSRD, while corporate social responsibility disclosure has a different influence on profitability (ROA, ROE, and NIM).

According to the findings, the average degree of corporate social transparency is low. The low-level transparency index items are used for a number of reasons. Non-compliance in Yemen may be the most critical explanation for those planning the financial reports of Yemeni Islamic banks who do not provide this kind of detail in external annual reports. Furthermore, the high cost of preparing and releasing reports to the public is another potential explanation for why commercial bank management may not be able to include such information.

\section{CONCLUSION}

The objective of this research is to explore the effect of corporate social responsibility transparency factors on Yemeni financial institutions' profitability over the twelve years period from 2005 to 2016. The results of this study show that corporate social responsibility, asset size, inflation rate, and age of Islamic banks have a significant influence on profitability (ROA). It is also suggested that financial leverage, asset size, and inflation rate are the most important variables affecting 
bank profitability (ROE). It was revealed that financial leverage and age of Islamic banks have a significant effect on profitability (PAT). Finally, the result also indicated that financial leverage, asset size, inflation rate, and age of Islamic banks have a significant impact on bank profitability (EPS).

Future studies can use Islamic financial institutions that apply other methods to reveal their financial and non-financial records, such as quarterly and interim reports, the Internet, bank circulars, and financial press releases; this study only looked at the amount of disclosure in annual reports of Yemeni Islamic banks. As a result, additional analysis can be done to look at voluntary disclosures made in quarterly financial statements or at the reporting level issued on Islamic banks' websites. According to this analysis, Yemen's Islamic banks should enhance the efficiency, accountability, and consistency of accounting disclosure and financial statements.

\section{AUTHOR CONTRIBUTIONS}

Conceptualization: Nabil Ahmed Mareai Senan, Aida Abdulaziz Ali Noaman, Eissa A. Al-Homaidi. Data curation: Aida Abdulaziz Ali Noaman, Borhan Omar Ahmad Al-dalaien, Eissa A. Al-Homaidi. Formal analysis: Nabil Ahmed Mareai Senan, Borhan Omar Ahmad Al-dalaien.

Investigation: Nabil Ahmed Mareai Senan, Aida Abdulaziz Ali Noaman, Eissa A. Al-Homaidi. Methodology: Nabil Ahmed M Aida Abdulaziz Ali Noaman, areai Senan, Borhan Omar Ahmad Aldalaien, Eissa A. Al-Homaidi.

Resources: Aida Abdulaziz Ali Noaman, Borhan Omar Ahmad Al-dalaien.

Software: Aida Abdulaziz Ali Noaman.

Supervision: Nabil Ahmed Mareai Senan, Aida Abdulaziz Ali Noaman, Eissa A. Al-Homaidi.

Validation: Nabil Ahmed Mareai Senan, Eissa A. Al-Homaidi.

Visualization: Aida Abdulaziz Ali Noaman, Eissa A. Al-Homaidi.

Writing - original draft: Aida Abdulaziz Ali Noaman, Borhan Omar Ahmad Al-dalaien, Eissa A.

Al-Homaidi.

Writing - reviewing \& editing: Nabil Ahmed Mareai Senan.

\section{REFERENCES}

1. Al-Homaidi, E. A., Al-Matari, E. M., Tabash, M. I., Khaled, A. S. D., \& Senan, N. A. M. (2021). The influence of corporate governance characteristics on profitability of Indian firms: An empirical investigation of firms listed on Bombay Stock Exchange. Investment Management and Financial Innovations, 18(1), 114-125. https://doi.org/10.21511/ imfi.18(1).2021.10

2. Al-Homaidi, E. A., Tabash, M. I., \& Ahmad, A. (2020). The profitability of islamic banks and voluntary disclosure: empirical insights from Yemen. Cogent Economics and Finance, 8(1), 1-22. https://doi.org/10.1080/233 22039.2020.1778406

3. Amran, A., Fauzi, H., Purwanto, Y., Darus, F., Yusoff, H., Zain,
M. M., Naim, D. M. A., \&

Nejati, M. (2017). Social responsibility disclosure in Islamic banks: a comparative study of Indonesia and Malaysia. Journal of Financial Reporting and Accounting, 15(1), 99-115. https://doi.org/10.1108/jfra-012015-0016

4. Barros, C. P., Boubaker, S., \& Hamrouni, A. (2013). Corporate governance and voluntary disclosure in France. The Journal of Applied Business Research, 29(2), 561-578. https://doi. org/10.19030/jabr.v29i2.7657

5. Belal, A. R. (2008). Corporate social responsibility reporting in developing countries: The case of Bangladesh. London: Routledge. https://doi. org/10.4324/9781315574332
6. Bolanle, A. B., Adebiyi, S. O., \& Muyideen, A. A. (2012). Corporate social responsibility and profitability of Nigeria Bbanks - A causal relationship. Research Journal of Finance and Accounting, 3(1), 6-18. Retrieved from https://www.iiste.org/ Journals/index.php/RJFA/article/ view/1298/1218

7. Chen, Y. C., Hung, M., \& Wang, Y. (2018). The effect of mandatory CSR disclosure on firm profitability and social externalities: Evidence from China. Journal of Accounting and Economics, 65(1), 169-190. https://doi.org/10.1016/j.jacceco.2017.11.009

8. Chiang, H., He, L.-J., \& Shiao, C.-F. (2015). Financial reports quality and corporate social responsibility. Asian 
Economic and Financial Review, 5(3), 453-467. https:// doi.org/10.18488/journal aefr/2015.5.3/102.3.453.467

9. Farook, S., Hassan, M. K., \& Lanis, R. (2011). Determinants of corporate social responsibility disclosure: the case of Islamic banks. Journal of Islamic Accounting and Business Research, 2(2), 114-141. https://doi. org/10.1108/17590811111170539

10. Gunningham, N., Kagan, R. A., \& Thornton, D. (2004). Social license and environmental protection: why businesses go beyond compliance. Law \& Social Inquiry, 29(2), 307-341. https://doi. org/10.1111/j.1747-4469.2004. tb00338.x

11. Hassan, A., \& Harahap, S. S. (2010). Exploring corporate social responsibility disclosure: the case of Islamic banks. International Journal of Islamic and Middle Eastern Finance and Management, 3(3), 203-227. https://doi. org/10.1108/17538391011072417

12. Hawashe, A. A.-M. (2014). An evaluation of voluntary disclosure in the annual reports of commercial banks: Empirical evidence from Libya (Doctoral Thesis). Retrieved from http://usir.salford.ac.uk/id/ eprint/31513/

13. Hopkins, M. (2004). Corporate social responsibility: an issues paper (Working Paper No. 27). Retrieved from https://www.ilo. org/legacy/english/integration/ download/publicat/4_3_285_wcsdg-wp-27.pdf

14. Hossain, M. (2008). The extent of disclosure in annual reports of banking companies: The case of India. European Journal of Scientific Research, 23(4), 659-680. Retrieved from http:// qspace.qu.edu.qa/bitstream/handle/10576/10429/ejsr_23_4_15. pdf

15. Hossain, M., \& Hammami, H. (2009). Voluntary disclosure in the annual reports of an emerging country: The case of Qatar. Advances in Accounting,
25(2), 255-265. https://doi. org/10.1016/j.adiac.2009.08.002

16. Lee, Y., \& Yang, L. T. (2021). Corporate social responsibility and financial performance: a case study based in Taiwan. Applied Economics, 53(23), 26612670. https://doi.org/10.1080/00 036846.2020.1866158

17. Lin, L., Hung, P. H., Chou, D. W., \& Lai, C. W. (2019). Financial performance and corporate social responsibility: Empirical evidence from Taiwan. Asia Pacific Management Review, 24(1), 61-71. https://doi. org/10.1016/j.apmrv.2018.07.001

18. Long, W., Li, S., Wu, H., \& Song, X. (2020). Corporate social responsibility and financial performance: The roles of government intervention and market competition. Corporate Social Responsibility and Environmental Management, 27(2), 525-541. https://doi. org/10.1002/csr.1817

19. Maqbool, S., \& Bakr, A. (2019). The curvilinear relationship between corporate social performance and financial performance. Journal of Global Responsibility, 10(1), 87-100. https://doi.org/10.1108/jgr-112018-0060

20. Maqbool, S., \& Zamir, M. N. (2019). Corporate social responsibility reporting in India: A Study of SENSEX Companies. Management and Labour Studies, 44(2), 209-223. https://doi. org/10.1177/0258042x19832122

21. Mirfazli, E. (2008). Corporate social responsibility (CSR) information disclosure by annual reports of public companies listed at Indonesia Stock Exchange (IDX). International Journal of Islamic and Middle Eastern Finance and Management, 1(4), 275-284. https://doi. org/10.1108/17538390810919592

22. Momin, M. A. (2006). Corporate social responsibility and reporting by multinational corporations in Bangladesh: an exploration (Ph.D.
Thesis). University of Glasgow. Retrieved from http://theses.gla. ac.uk/1074/

23. Ompusunggu, J. (2016). The effect of profitability to the disclosure of corporate social responsibility (CSR disclosure) on mining companies listed on Indonesian Stock Exchange (BEI) in the Year 2010-2012. IOSR Journal of Business and Management (IOSR-JBM), 18(6), 69-78. Retrieved from http:// iosrjournals.org/iosr-jbm/papers/Vol18-issue6/Version-1/ I1806016978.pdf

24. Platonova, E., Asutay, M., Dixon, R., \& Mohammad, S. (2016). The impact of corporate social responsibility disclosure on financial performance: evidence from the GCC Islamic Banking Sector. Journal of Business Ethics, 151(2), 451-471. https://doi. org/10.1007/s10551-016-3229-0

25. Quazi, A., Nejati, M., \& Amran, A. (2015). The CSR journey: looking through the evolutionary lens. In M. Nejati, A. Quazi, \& A. Amran (Eds), Corporate Social Responsibility and Sustainability: Contemporary Perspectives. PEARSON, Kuala Lumpur. Retrieved from https:// researchprofiles.canberra.edu.au/ en/publications/the-csr-journeylooking-through-the-evolutionary-lens

26. Rahman, A. A., \& Bukair, A. A. (2013). The influence of the Sariah supervision board on corporate social responsibility disclosure by Islamic banks of Gulf Co-Operation Council Countries. Asian Journal of Business and Accounting, 6(2), 65-104. Retrieved from https://ajba.um.edu.my/article/ view/2678

27. Ridwan, R., \& Mayapada, A. G. (2020). Does sharia governance influence corporate social responsibility disclosure in Indonesia Islamic. Journal of Sustainable Finance \& Investment, 2020, 1-20. https://doi.org/10.10 80/20430795.2020.1749819

28. Rodrguez, L. C., \& Lemaster, J. (2007). Voluntary corporate social responsibility 
disclosure: SEC "CSR seal of approval." Business and Society, 46(3), 370-384. https://doi. org/10.1177/0007650306297944

29. Szegedi, K., Khan, Y., \& Lentner, C. (2020). Corporate Social Responsibility and Financial Performance: Evidence from Pakistani Listed Banks. Sustainability, 12(10), 1-19. https://doi.org/10.3390/ su 12104080

30. Tran, Q. T., Vo, T. D., \& Le, X. T. (2021). Relationship between profitability and corporate social responsibility disclosure: Evidence from Vietnamese listed banks. Journal of Asian Finance, Economics and Business, 8(3), 875-883. https://doi. org/10.13106/jafeb.2021.vol8. no3.0875

31. Visser, W., Matten, D., Pohl, M., \& Tolhurst, N. (2008).

The A to $Z$ of corporate social responsibility: The complete reference of concepts, codes and organization. John Wiley \& Sons Ltd. Retrieved from https:// ua1lib.org/book/841277/-b1e02d ?id $=841277 \&$ secret $=$ b1e02d

32. Wuttichindanon, S. (2017). Corporate social responsibility disclosure $\mathrm{d}$ choices of report and its determinants: Empirical evidence from firms listed on the Stock Exchange of Thailand. Kasetsart Journal of Social Sciences, 38(2), 156162. https://doi.org/10.1016/j. kjss.2016.07.002 